\title{
Article \\ Satisfaction with Self and External Regulation of Learning in Higher Education Students in Brazil
}

\author{
Lucía Herrera Torres ${ }^{1}\left(\mathbb{D}\right.$, Mara Rachel Souza-Soares de Quadros ${ }^{2}$, Laura C. Sánchez-Sánchez ${ }^{1, *(1)}$ \\ and Tamara Ramiro-Sánchez ${ }^{1}$ \\ 1 Department of Developmental and Educational Psychology, Faculty of Science Education and Sport, \\ University of Granada, Calle Santander, N 1, 52071 Melilla, Spain; luciaht@ugr.es (L.H.T.); \\ tramiro@ugr.es (T.R.-S.) \\ 2 Centro de Convergência, Campus Morro do Cruzeiro, Universidade Federal de Ouro Preto, \\ Ouro Preto 35400-000, Brazil; mara.rachel@ufop.edu.br \\ * Correspondence: lcsanchezsa@ugr.es; Tel.: +34-952698731
}

check for updates

Citation: Herrera Torres, L.; Souza-Soares de Quadros, M.R.;

Sánchez-Sánchez, L.C.;

Ramiro-Sánchez, T. Satisfaction with Self and External Regulation of Learning in Higher Education Students in Brazil. Int. J. Environ. Res. Public Health 2021, 18, 5914. https:// doi.org/10.3390/ijerph18115914

Academic Editor: Paul B. Tchounwou

Received: 28 April 2021

Accepted: 27 May 2021

Published: 31 May 2021

Publisher's Note: MDPI stays neutra with regard to jurisdictional claims in published maps and institutional affiliations.

Copyright: (c) 2021 by the authors. Licensee MDPI, Basel, Switzerland This article is an open access article distributed under the terms and conditions of the Creative Commons Attribution (CC BY) license (https:// creativecommons.org/licenses/by/ $4.0 /)$.

\begin{abstract}
The satisfaction of university students with the variables that regulate their learning provides very valuable information to improve the quality of teaching processes. The main objective of this study was to evaluate the learning of Brazilian university students, exploring both selfregulation variables, such as study techniques; and more external regulation variables, namely, satisfaction with the teaching-learning process and with the infrastructure, based on three variables: gender, the institution of higher education and the academic year of the students. To achieve this, 560 students of the Pedagogy degree were evaluated with two questionnaires: a questionnaire of satisfaction with the educational infrastructure and the teaching-learning process and a questionnaire on study techniques. Statistically significant differences were obtained, especially depending on the type of institution and the academic year. The students of private schools and earlier academic years were the ones who obtained the most satisfaction with the study techniques and with the infrastructure. Those from private centers also expressed more satisfaction with the teaching-learning processes. These results provide greater knowledge about the processes of self-regulation and external regulation of university learning and of their satisfaction with them, which can contribute to improving educational policies in Brazil.
\end{abstract}

Keywords: self-regulation; external regulation; study techniques; teaching-learning processes; educational infrastructure; type of institution; academic year

\section{Introduction}

University learning and the many issues that it entails has become a highly relevant topic in political and academic debates [1,2]. In this framework, there have been multiple research focuses used to evaluate university learning, from the way in which students regulate their learning and how teachers perform, to the contextual and organizational factors of the institutions [3-5]. In recent decades, higher education institutions, with the aim of offering a favorable learning environment, have highlighted the importance of considering in-learning assessment: student satisfaction with the teaching-learning process through the teaching performance (i.e., the level of experience; teacher-student relationship; mastery of the content; pedagogical resources used, such as audiovisual, multimedia or laboratory and others) and with the educational infrastructure [6-11].

The way in which students learn is a crucial issue in the context of higher education due to its implication in aspects such as university dropouts, academic performance, difficulties in accessing the labor market or student satisfaction [12-16]. So much so that, as argued by Hagström and Lindberg [17], there are many investigations that have displaced the object of attention from the teaching action towards the student's learning. 
In this sense, university learning is a complex process, which is made up of a range of constructs such as learning approaches, learning styles, learning strategies, study techniques, self-regulated learning or study habits, among others [18-22]. Regarding this topic, the idea that students learn in different ways is defended, since they use a series of activities and strategies to apprehend the contents [23,24]. In other words, learning takes place through cognitive processing activities, affective/motivational activities, and self-regulation activities [25-27]. In relation to this, scientific literature has shown that the learning process is influenced by the interaction of personal and contextual factors, which condition the learning outcome $[28,29]$. Among personal aspects, age, personality, motivation and learning styles have been highlighted; while in contextual aspects, teaching methods, types of evaluation and academic interactions have been identified [30-34].

In this scenario, the concept of self-regulated learning deserves a special mention by emphasizing the way in which students see themselves as learners [35], in the sense of developing in themselves certain academic skills, such as setting objectives, selecting strategies and self-assessing their learning, that is, as active and constructive individuals [36]. This proactive stance is based on feelings and motivational beliefs and the use of metacognitive strategies [37,38]. As Pintrich and García [39] state, self-regulated learning is governed by metacognitive control (planning, monitoring and regulation of the activities carried out during learning) and by resource management strategies with respect to time and study space. In this framework, some research has shown that university students who use self-regulation strategies to learn, obtain higher academic performance as well as higher academic satisfaction $[7,31]$. Consequently, different studies highlight the importance of educators informing and training their students in the development of self-regulatory capacities $[7,38,40,41]$.

In the current context, one of the most significant concerns for Educational Psychology is student behavior towards their own learning [31]. This is due to the role that the student assumes in their "learning to learn" process, which justifies the need to know, on the one hand, how students deal with the learning process [32] and, on the other hand, the teaching methodologies and teaching strategies adopted, with a view to improving learning outcomes, particularly after the Bologna Plan $[40,42,43]$.

From this perspective, the way the teacher educates and the strategies they use influence the way the student chooses the techniques to be employed and copes with studying [23]. However, it must be emphasized that lectures still predominate in higher education, with an emphasis on content and not on competencies, centered on the figure of the teacher, which results in less reflective students [44-46], who use processes of superficial learning aimed at reproducing "models", and for this reason, make use of less elaborate learning strategies, for example, the taking of nongenerative notes, without a conscious or intentional use $[3,47,48]$. In contrast, there are university students who use deep learning processes, which imply intrinsic motivation to learn and use more elaborate learning strategies, together with self-regulation activities [24,49], which are favored when teachers use a regulatory teaching method, that is, one which focuses especially on helping students to self-regulate their learning process [7,41].

Linked to the above, gender and academic year are some of the variables that have been frequently related to the use of learning strategies by university students [50-55]. Some research shows that women use self-regulation strategies more frequently than men $[50,53,55]$, as well as obtaining higher scores than men in strategies of testing, elaboration, organization and metacognitive processing [52]. However, other investigations have not found differences based on gender [56-59] or find them mediated by the type of degree being studied [60] or by age [61]. With regard to the academic year, some research reports that it is students in higher academic years that make greater use of learning strategies and are more effective than those used by students in lower academic years $[51,54]$. There is, however, research such as that of Lynch [52], which points to a decrease in the maintenance of effort in higher academic years compared to lower ones. In the same vein, in a systematic review on the evolution of the development of learning approaches in university students, 
the authors concluded that the reviewed studies do not provide clear empirical evidence for the assumption that students of higher academic years or levels develop deeper or more elaborate learning strategies and approaches [62].

On the other hand, in this student-centered context, student satisfaction emerges as an extremely relevant aspect as a tool for evaluating learning in institutions of higher education (IHEs) [63,64], considered a pedagogical device [65] which is influenced by student life at the university [66]. Through student satisfaction, the motivation and permanence of the students can be achieved [67], guarantee better learning results [68], contribute to greater competitiveness [69], favor enrollment in undergraduate and postgraduate studies [70], as well as promote greater loyalty and trust [71,72], among other aspects.

Scientific literature lists a variety of factors that predict student satisfaction, including the quality of the teaching-learning process [6,73-75], as well as aspects related to the educational infrastructure, such as administrative staff $[73,76-78]$, university facilities [65,79-81], location $[65,78]$ and technological resources [66]. In this sense, educational technology should be highlighted as an important factor that influences student satisfaction, both with the educational infrastructure through the availability of technological resources and the support of information technologies [66], and with the teaching-learning process, by means of the use of technological resources by teachers [74].

Regarding satisfaction with the teaching-learning process through the teaching performance, this appears in a wide variety of studies as an important explanatory factor of overall satisfaction of university students $[74,77,82,83]$. Furthermore, satisfaction with the teaching-learning process has been related to the use of deeper or self-regulated learning strategies $[61,84,85]$, as well as higher academic performance in university students [7]. Similarly, some studies highlight the influence of gender on satisfaction with the teachinglearning process, although with contradictory results $[74,86]$. In this way, while Poon's [74] research carried out on university students in the United Kingdom, revealed that women showed a lower level of satisfaction with the teaching-learning process than men, in O'Driscoll's [86] research with Irish university students, they did not find statistically significant differences based on gender. Even other research has shown that these gender differences could be mediated by the use of a deeper learning approach and the age of university students [61]. Furthermore, although to a lesser extent, the type of institution (public or private) has been identified as an influential factor in satisfaction with the teaching-learning process, with university students from public institutions showing greater satisfaction [87].

In relation to satisfaction with the educational infrastructure, there are multiple studies that have empirically verified that facilities are indicated as a determining element for satisfaction by students from different areas of knowledge and in different countries, taking into account various aspects: library, communal areas, computers, classroom spaces, number of students per class, accommodation services, restaurant and sports, among others $[78,79,88]$. Regarding satisfaction with the educational infrastructure, according to gender, some studies do not find statistically significant differences [79,89], while others report that women are more satisfied than men [73]. Regarding the type of institution, the majority of research shows greater satisfaction with the infrastructure in private institutions $[75,76,90]$. However, in other investigations, it should be noted that it was students from public institutions who reported greater satisfaction with aspects related to infrastructure, such as library facilities or technological resources [87]. Likewise, some studies highlight an inverse relationship between the academic year and satisfaction with the educational infrastructure, with students in more advanced academic years showing the least satisfaction with educational infrastructure [65,73].

Taking into account the aforementioned, together with the fact that in Brazil there is little scientific production on university learning, and the satisfaction of students has still not been explored enough [91], interest in investigating these aspects is corroborated. Therefore, the first objective of this research is to evaluate the learning of Brazilian university students considering study techniques (study place and conditions, study organization 
and learning strategies), satisfaction with the teaching-learning process and with the educational infrastructure based on three variables: gender, institution of higher education and, the academic year of the Degree of Pedagogy students in the city of São Luís-Maranhão (Brazil). The second objective is to analyze the influence of age, gender, academic year, and institution on the general satisfaction of said students with respect to the educational infrastructure, the teaching-learning process and the study techniques used.

\section{Materials and Methods}

\subsection{Participants}

The sample consisted of 560 Brazilian students of the Pedagogy Degree $(90.36 \%$ women and $9.64 \%$ men), with a minimum age of 16 and a maximum of 56 years old $(\mathrm{M}=26.26 ; \mathrm{SD}=8.19)$. As can be seen, the Pedagogy Degree is studied mostly by women. The minimum age for starting university studies in Brazil is 16 years old. However, it is common for the age to be very diverse since students can start their studies later, because they did not start at a younger age, or because it is taken as a second degree.

These students were in each of the four academic years that make up the degree, that is, 1 st year $(n=150 ; 26.8 \%)$, 2nd year $(n=140 ; 25.0 \%)$, 3rd year $(n=127 ; 22.7 \%)$ and 4 th year $(n=143 ; 25.5 \%)$. They also attended classes in person at three higher education institutions in São Luís-Maranhão (Brazil): Universidade Estadual do Maranhão (UEMA) $(n=153 ; 27.3 \%)$, Universidade Federal do Maranhão (UFMA) $(n=235 ; 42 \%)$ and Faculdade Pythagoras (FP) $(n=172 ; 30.7 \%)$. The first two institutions are public and the last is private. Table 1 presents the description of the participants according to these variables.

Table 1. Characteristics of the participants of this study.

\begin{tabular}{ccccccccc}
\hline \multirow{2}{*}{ IHE } & $\begin{array}{c}\text { Academic } \\
\text { Year }\end{array}$ & \multicolumn{3}{c}{ Gender } & \multicolumn{5}{c}{ Edad } \\
\cline { 2 - 8 } & Male & Female & Total & Minimum & Maximum & $\boldsymbol{M}$ & SD \\
\hline \multirow{3}{*}{ UEMA } & $1 .^{\circ}$ & 2 & 43 & 45 & 16 & 35 & 21.73 & 4.42 \\
& $2 .^{\circ}$ & 2 & 31 & 33 & 18 & 38 & 22.78 & 5.12 \\
& $3 .^{\circ}$ & 3 & 30 & 33 & 19 & 56 & 26.74 & 10.24 \\
& $4 .^{\circ}$ & 3 & 39 & 42 & 19 & 37 & 23.40 & 3.44 \\
UFMA & $1 .^{\circ}$ & 6 & 53 & 59 & 17 & 40 & 22.75 & 4.95 \\
& $2 .^{\circ}$ & 6 & 71 & 77 & 18 & 56 & 26.10 & 8.71 \\
& $3 .^{\circ}$ & 11 & 42 & 53 & 19 & 49 & 28.52 & 9.55 \\
& $4 .^{\circ}$ & 9 & 37 & 46 & 20 & 53 & 28.15 & 8.96 \\
FP & $1 .^{\circ}$ & 3 & 43 & 46 & 18 & 48 & 27.37 & 8.73 \\
& $2 .^{\circ}$ & 3 & 27 & 30 & 19 & 49 & 27.35 & 7.42 \\
Total & $3 .^{\circ}$ & 4 & 37 & 41 & 20 & 46 & 30.15 & 7.48 \\
& $4 .^{\circ}$ & 2 & 53 & 55 & 20 & 50 & 29.81 & 7.89 \\
& & 54 & 506 & 560 & 16 & 56 & 26.26 & 8.19 \\
\hline
\end{tabular}

Note. IHE = Institution of Higher Education; UEMA = State University of Maranhão; UFMA = Federal University of Maranhão; FP = Faculdade Pythagoras; $\mathrm{M}=$ mean; $\mathrm{SD}$ = standard deviation.

Regarding the way students access university, 55.66\% opted for the National High School Exam while the rest (44.4\%) accessed after passing a specific exam at the university to which they aspired.

Ethnic-racial diversity in the sample is very wide, as occurs in the Brazilian population. In this regard, although the majority are mulattoes (57.53\%), there were also whites (20.15\%), blacks (19.24\%), Asians (2.54\%) and indigenous people (0.54\%). Likewise, 50.2\% did not work, while $49.8 \%$ did. In the latter, $30.1 \%$ worked in the education sector and $19.7 \%$ in other sectors.

\subsection{Instruments}

First of all, a section on sociodemographic data was included, such as age, gender, place of birth, institution of higher education, academic year and semester, shift, access route to university, etc. 
Secondly, two questionnaires were used, one aimed at evaluating student satisfaction with respect to the educational infrastructure and the teaching-learning process and the other at evaluating the study techniques used by students.

2.2.1. Satisfaction Questionnaire with the Educational Infrastructure and the Teaching-Learning Process

A questionnaire was designed based on different studies that focus on the relevance of educational facilities in higher education $[70,78,79,81,92]$ as well as the teaching-learning process [6,8,93-95].

This questionnaire, made up of 63 items, was submitted to content validation, using the expert judgment technique. Ten specialists from different areas of higher education participated (Education, Psychology and Educational Research Methods) who were asked to respond on a Likert-type scale from 1 to 4 , on the clarity of the writing and the relevance of the content of the items. The criteria established by Barbero [96] for inter-judge agreement were followed, that is:

- That the mean value of each item was equal to or greater than 2.5.

- Pay attention to the median value, as the value of the item.

- The 50th percentile (p. 50) should obtain values equal to or greater than 2.5.

- An ambiguity coefficient was established, which was intended to measure dispersion in the judges' agreement, using the interquartile range as a criterion. Thus, if the difference between the 75th percentile (p.75) and the 25th percentile (p.25) was equal to 0 or 1, the item was accepted and/or slightly modified; If the difference was between 1 and 2, the item was revised and reformulated; whereas, if it was higher than 2, it was understood that the dispersion was high among the judges' criterion, so the item was rejected.

After this process, four items were reviewed and their wording was modified, depending on the coefficient of ambiguity obtained (between 1.25 and 1.50) and the comments provided by the judges.

Subsequently, a pilot test was carried out with 15 students of the Pedagogy Degree from a higher education institution with the same characteristics necessary for the sample. This test also permitted observation of the time taken to answer the questions, as well as perceiving comprehension difficulties. Observations of the students regarding any terms not understood or the wording of some items were collected, proceeding to slight change in the wording of three items and inclusion of the response options regarding satisfaction with the educational infrastructure "Does not exist" and "I do not know".

The final questionnaire was subsequently made up of 63 items structured in six categories: support infrastructure- external services, for example, banks (4 items); support infrastructure-internal services, such as conference or auditorium spaces (17 items); library resources, for instance, hard copies physically available in the library, that is, books, journals, dictionaries, encyclopedias, etc. (10 items); classroom facilities, for example, the size of the classroom (8 items); technological resources, such as computer rooms ( 7 items); teaching-learning process, for instance, teaching methodologies (17 items).

It had to be answered following a four-point Likert-type scale, where $1=$ Totally dissatisfied and $4=$ Totally satisfied. Likewise, regarding satisfaction with the educational infrastructure, the options "NE = Does not exist" and "NK = I do not know" were included.

The reliability of the questionnaire, evaluated using the Cronbach's alpha internal consistency index, was 0.926 .

\subsubsection{Study Techniques Questionnaire}

A linguistic and cultural adaptation to the Brazilian context of the Study Techniques Questionnaire by Herrera and Gallardo [97] was used. In order to carry this out, indications outlined by the International Test Commission [98] were followed. These criteria have been widely used in the adaptation of tests [99]. In this regard, there was the participation of six Brazilian experts (three psychologists and three pedagogues), fluent in Spanish. 
They made the linguistic and cultural adaptation of the questionnaire, using a direct and inverse translation of the original instrument. Likewise, they attended to its content validity through the same procedure indicated in the previous questionnaire.

On the other hand, the test was also passed in a pilot study to 15 Pedagogy students and the wording of three of the items was slightly modified for a better understanding of them.

The final questionnaire was made up of 65 items, which referred to three categories: study place and conditions, for example, "Study in my bedroom" (17 items); organization of the study, for instance, "I usually plan the time that I am going to dedicate to the study" (15 items) and learning strategies, for example, "When I study, I relate the contents of the subject with those of other subjects" (33 items).

The students were asked to respond to a four-point Likert-type scale, where $1=$ Never and $4=$ Always.

The original version, in Spanish, of the Study Techniques Questionnaire has a reliability of 0.720 [100]. In this study, an internal consistency index of 0.828 was found.

\subsection{Procedure}

\subsubsection{Data Collection}

Firstly, the approval of this study was obtained from the Brazilian Ethics Committee, following the ethical standards for the development of research with human beings, which was approved with reference code No. 3042080. Secondly, meetings were held with the heads of the six IHEs that offer the Pedagogy Course in the city of São Luís, presenting the research project, the data collection instruments and clarifying any possible doubts that might arise. Of the six institutions, three gave a positive response. Therefore, thirdly, a legal representative of each participating institution signed a formal authorization of the same, in which it was indicated, among other aspects, that the institutions could request more information regarding the study, authorizing the disclosure of data for scientific/academic purposes, respecting institutional secrecy and, in addition, that they would provide the requested results.

Once the different institutional authorizations had been obtained, the students were informed of the main objectives of the research and the instruments were designed. Those students who signed the Informed Consent were part of the sample. Likewise, the Informed Consent established that it was an anonymous, voluntary participation, without financial compensation and that they could stop their participation at any time. In addition, it was specified that the results of the study could be published in scientific/academic media.

The information collection instruments were applied in the second semester of the academic year at the beginning of the class schedule of a subject, in order to avoid major interruptions in the routine. Previously, a brief explanation of the instruments was provided, and they were read to resolve any questions. The mean time required to answer both instruments was 20-30 min.

\subsubsection{Analysis of Data}

For data analysis, the statistical program IBM SPSS Statistics version 25 was used. Before starting with the different statistical analyses based on the research objectives, we proceeded to determine if the data fulfilled the normality criterion (Gaussian distribution), as well as the homogeneity of variances, in order to implement parametric or nonparametric statistical analysis tests.

To determine the normal distribution of the data, the Kolmogorov-Smirnov test was used, obtaining significant values for all items of the questionnaire, $p<0.001$. Therefore, the Gaussian distribution was not satisfied. On the other hand, the homoscedasticity or homogeneity of variances was calculated. In the case of the independent variables gender (male vs. female) and type of IHE (public vs. private), the Levene statistic was used with the $t$-test for independent samples, not reaching the level of significance, $p>0.05$, while for the variable grade (1st to 4 th) the analysis of variance was used. No statistically significant 
results were obtained. Consequently, the homogeneity or equality of variances between the comparison groups was fulfilled.

In light of these results, some authors indicate that when normality is not fulfilled, nonparametric tests must be used [101]. However, given the size of the sample and that the requirement of homogeneity of variances was met, parametric statistical analysis tests were used, in the direction pointed out by different authors [102,103].

The mean score for each category of the two questionnaires was calculated. Likewise, the analysis of variance was used for the analysis based on the variables gender, type of IHE and academic year. The effect size was also analyzed, through the partial eta ${ }^{2}$ test, considering the following indices: $\eta^{2} p=0.01$ (small effect); $\eta^{2} p=0.06$ (medium effect); $\eta^{2} p=0.14$ (large effect) [104]. For the analysis of the effect size in the variables with two levels, Cohen's d was used. In the case of the academic year variable, with four levels, the selected statistic for post-hoc comparisons was the Bonferroni test.

To respond to the second research objective, the mean score for satisfaction with the educational infrastructure, satisfaction with the teaching-learning process and study techniques was calculated. A linear regression analysis was developed in which, as a dependent variable, each of these variables were entered; and age, gender, grade, and type of IHE were entered as independent variables.

\section{Results}

\subsection{Total Results}

Table 2 shows the descriptive statistics obtained in each of the categories that make up the two evaluation instruments used.

Table 2. Descriptive statistics in each category of the questionnaires.

\begin{tabular}{|c|c|c|c|c|c|c|}
\hline & Categories & $N$ & Minimum & Maximum & $M$ & $S D$ \\
\hline \multirow{5}{*}{$\begin{array}{c}\text { Satisfaction with the } \\
\text { educative } \\
\text { infrastructure }\end{array}$} & Support infrastructure-external services & 560 & 1.00 & 4.00 & 2.37 & 0.44 \\
\hline & Support infrastructure-internal services & 560 & 1.00 & 4.00 & 2.28 & 0.47 \\
\hline & Library resources & 560 & 1.00 & 4.00 & 2.48 & 0.65 \\
\hline & Classroom facilities & 560 & 1.00 & 4.00 & 2.77 & 0.63 \\
\hline & Technological resources & 560 & 1.00 & 4.00 & 2.20 & 0.61 \\
\hline $\begin{array}{c}\text { Satisfaction with the } \\
\text { teaching-learning } \\
\text { process }\end{array}$ & Teaching-learning process & 560 & 1.00 & 4.00 & 2.70 & 0.52 \\
\hline \multirow{3}{*}{ Study techniques } & Study place and conditions & 560 & 1.00 & 4.00 & 2.12 & 0.31 \\
\hline & Study organization & 560 & 1.00 & 4.00 & 2.35 & 0.39 \\
\hline & Learning strategies & 560 & 1.00 & 4.00 & 2.60 & 0.35 \\
\hline
\end{tabular}

Note. $M=$ mean; $S D=$ standard deviation.

In general, the score achieved in satisfaction with the different elements raised was average. As can be seen, the highest scores were those related to satisfaction with classroom facilities $(M=2.77, S D=0.63)$ and with the teaching-learning process $(M=2.70, S D=0.52)$, while the lowest ones refer to the place and study conditions $(M=2.12, S D=0.31)$ as well as the technological resources $(M=2.20, S D=0.61)$.

\subsection{Analysis Based on the Variables Gender, Type of IHE and Academic Year}

Table 3 presents the results of the three analysis of variance implemented based on the comparison variables. 
Table 3. Main effects of the comparison variables.

\begin{tabular}{cccc}
\hline Variables & $\mathbf{F}$ & $\boldsymbol{p}$ & Eta $^{2} \mathbf{p}$ \\
\hline Gender & 1.470 & 0.156 & 0.024 \\
Type of IHE & $8.272^{* * *}$ & 0.000 & 0.119 \\
Academic year & $27.000^{* * *}$ & 0.000 & 0.041 \\
\hline
\end{tabular}

No statistically significant differences were found based on gender, although there were on the type of IHE and the academic year. The results in each category of the questionnaires are shown in Table 4.

Table 4. Analysis of variance in each category according to gender, type of IHE and academic year.

\begin{tabular}{|c|c|c|c|c|c|c|c|c|c|c|}
\hline & \multirow[b]{2}{*}{ Categories } & \multicolumn{3}{|c|}{ Gender } & \multicolumn{3}{|c|}{ Type of IHE } & \multicolumn{3}{|c|}{ Academic Year } \\
\hline & & F & $p$ & $\operatorname{Eta}^{2} p$ & F & $p$ & $\operatorname{Eta}^{2} p$ & F & $p$ & $\operatorname{Eta}^{2} p$ \\
\hline \multirow{5}{*}{$\begin{array}{l}\text { Satisfaction with the } \\
\text { educative } \\
\text { infrastructure }\end{array}$} & $\begin{array}{l}\text { Support infrastructure-External } \\
\text { services }\end{array}$ & 3.029 & 0.082 & 0.005 & $8.845^{* *}$ & 0.003 & 0.016 & $4.959 * *$ & 0.002 & 0.026 \\
\hline & $\begin{array}{c}\text { Support infrastructure-Internal } \\
\text { services }\end{array}$ & 0.002 & 0.966 & 0.000 & $22.454^{* * *}$ & 0.000 & 0.039 & $10.807^{* * *}$ & 0.000 & 0.055 \\
\hline & Library resources & 1.914 & 0.167 & 0.003 & $48.385^{* * *}$ & 0.000 & 0.080 & $11.645^{* * *}$ & 0.000 & 0.059 \\
\hline & Classroom facilities & 0.101 & 0.750 & 0.000 & 2.049 & 0.153 & 0.004 & $8.906 * * *$ & 0.000 & 0.046 \\
\hline & Technological resources & 1.277 & 0.259 & 0.002 & $17.079 * * *$ & 0.000 & 0.030 & $7.677^{* * *}$ & 0.000 & 0.040 \\
\hline \multirow[t]{2}{*}{$\begin{array}{l}\text { Satisfaction with the } \\
\text { teaching-learning } \\
\text { process }\end{array}$} & Teaching-learning process & 1.108 & 0.293 & 0.002 & $19.601 * * *$ & 0.000 & 0.034 & 2.134 & 0.095 & 0.011 \\
\hline & Study place and conditions & 0.729 & 0.394 & 0.001 & 0.061 & 0.805 & 0.000 & 1.337 & 0.261 & 0.007 \\
\hline \multirow{2}{*}{ Study techniques } & Study organization & 0.064 & 0.800 & 0.000 & $10.881^{* *}$ & 0.001 & 0.019 & 1.925 & 0.124 & 0.010 \\
\hline & Learning strategies & 2.309 & 0.129 & 0.004 & $6.755^{*}$ & 0.010 & 0.012 & $3.522 *$ & 0.015 & 0.019 \\
\hline
\end{tabular}

*** $p<0.001,{ }^{* *} p<0.001,{ }^{*} p<0.05$.

Satisfaction in public IHEs was lower than in private ones with respect to the support infrastructure-external services $\left(M_{\text {public }}=2.33, S D=0.43 ; M_{\text {private }}=2.46, S D=0.48\right.$; $\mathrm{d}=-0.28)$, support infrastructure-internal services $\left(M_{\text {public }}=2.22, S D=0.45 ; M_{\text {private }}=2.42\right.$, $S D=0.49 ; \mathrm{d}=-0.42)$, library resources $\left(M_{\text {public }}=2.36, S D=0.62 ; M_{\text {private }}=2.77, S D=0.66\right.$; $\mathrm{d}=-0.64)$, the technological resources $\left(M_{\text {public }}=2.14, S D=0.55 ; M_{\text {private }}=2.37, S D=0.71\right.$; $\mathrm{d}=-0.36)$ and the teaching-learning process $\left(M_{\text {public }}=2.68, S D=0.47 ; M_{\text {private }}=2.86\right.$, $S D=0.62 ; \mathrm{d}=-0.33)$. In the same direction, differences were found in study techniques in relation to the organization of the study $\left(M_{\text {public }}=2.32, S D=0.36 ; M_{\text {private }}=2.44, S D=0.46\right.$; $\mathrm{d}=-0.29)$ and learning strategies $\left(M_{\text {public }}=2.58, S D=0.33 ; M_{\text {private }}=2.67, S D=0.39\right.$; $\mathrm{d}=-0.25)$.

By academic year, post-hoc comparisons using the Bonferroni test showed that satisfaction with the support infrastructure-external services was higher in the first year $(M=2.48, S D=0.44)$ compared to the third $(M=2.32, S D=0.42 ; p=0.014)$ and fourth $(M=2.30, S D=0.47 ; p=0.003)$. Satisfaction with the support infrastructure-internal services was higher in first $(M=2.46, S D=0.48)$ compared to second $(M=2.22, S D=0.45$; $p=0.000)$, third $(M=2.21, S D=0.40 ; p=0.000)$ and fourth $(M=2.20, S D=0.48 ; p=0.000)$. Also satisfaction with the library resources in the first year $(M=2.75, S D=0.64)$ compared to second $(M=2.40, S D=0.66 ; p=0.000)$, third $(M=2.38, S D=0.54 ; p=0.000)$ and fourth $(M=2.38, S D=0.68 ; p=0.000)$. Satisfaction with the classroom facilities, again, was higher in first $(M=2.99, S D=0.59)$ compared to second $(M=2.73, S D=0.62 ; p=0.002)$, third $(M=2.65, S D=0.60 ; p=0.000)$ and fourth $(M=2.69, S D=0.65 ; p=0.000)$. Satisfaction with technological resources, likewise, was higher in the first $(M=2.40, S D=0.58)$ than in the second $(M=2.16, S D=0.62 ; p=0.005)$, third $(M=2.06, S D=0.52 ; p=0.000)$ and fourth $(M=2.19, S D=0.67 ; p=0.019)$. For its part, the learning strategies used by the students were significantly higher in the first year $(M=2.64, S D=0.34)$ compared to the third $(M=2.53, S D=0.32 ; p=0.019)$.

\subsection{Predictive Analysis}

Firstly, a linear regression analysis was carried out in which satisfaction with the infrastructure was introduced as the dependent variable and gender, type of IHE, grade 
and age as predictive variables (see Table 5). The model was significant, $F=14.921$, $p=0.000$. Durbin-Watson's $d$ test showed that there was no autocorrelation in the data $(d=1505)$. Values of the Durbin-Watson test between 1.5 and 2.5 indicate that the data are not correlated [105]. In addition, the variance inflation factor (VIF) obtained values lower than 5, so multicollinearity was not present $[106,107]$.

Table 5. Regression analysis regarding satisfaction with the infrastructure.

\begin{tabular}{|c|c|c|c|c|c|c|c|}
\hline \multirow[t]{2}{*}{ Variables } & \multicolumn{2}{|c|}{$\begin{array}{l}\text { Non-Standardized } \\
\text { Coefficients }\end{array}$} & \multirow{2}{*}{$\begin{array}{c}\begin{array}{c}\text { Standardized } \\
\text { Coefficients }\end{array} \\
\text { Beta }\end{array}$} & \multirow{2}{*}{$t$} & \multirow{2}{*}{$p$} & \multicolumn{2}{|c|}{$\begin{array}{l}\text { Colinearity } \\
\text { Tests }\end{array}$} \\
\hline & B & SE & & & & TI & VIF \\
\hline Gender & -0.048 & 0.067 & -0.029 & -0.711 & 0.477 & 0.983 & 1.018 \\
\hline Type of IHE & 0.231 & 0.042 & 0.233 & $5.560 * * *$ & 0.000 & 0.948 & 1.055 \\
\hline Academic year & -0.092 & 0.017 & -0.230 & $-5.527 * * *$ & 0.000 & 0.961 & 1.040 \\
\hline Age & -0.003 & 0.002 & -0.050 & -1.186 & 0.236 & 0.918 & 1.089 \\
\hline
\end{tabular}

*** $p<0.001 ; S E=$ standard error; TI = tolerance index; VIF = variance inflation factor.

The type of IHE predicted satisfaction with the infrastructure and the academic year, in the latter case, the prediction was negative.

Secondly, a linear regression analysis was carried out in which satisfaction with the teaching-learning process was introduced as a dependent variable (see Table 6). The model was significant, $F=6.449, p=0.000$. The data were not correlated $(d=1658)$ and no multicollinearity was found.

Table 6. Regression analysis regarding satisfaction with the teaching-learning process.

\begin{tabular}{|c|c|c|c|c|c|c|c|}
\hline \multirow[t]{2}{*}{ Variables } & \multicolumn{2}{|c|}{$\begin{array}{l}\text { Non-Standardized } \\
\text { Coefficients }\end{array}$} & \multirow{2}{*}{$\begin{array}{c}\begin{array}{l}\text { Standardized } \\
\text { Coefficients }\end{array} \\
\text { Beta }\end{array}$} & \multirow[t]{2}{*}{$t$} & \multirow{2}{*}{$p$} & \multicolumn{2}{|c|}{$\begin{array}{l}\text { Colinearity } \\
\text { Tests }\end{array}$} \\
\hline & B & SE & & & & TI & VIF \\
\hline Gender & 0.016 & 0.079 & 0.008 & 0.198 & 0.843 & 0.983 & 1.018 \\
\hline Type of IHE & 0.222 & 0.049 & 0.197 & $4.564^{* * *}$ & 0.000 & 0.948 & 1.055 \\
\hline Academic year & -0.035 & 0.020 & -0.076 & -1.786 & 0.075 & 0.961 & 1.040 \\
\hline Age & -0.006 & 0.003 & -0.086 & -1.974 * & 0.049 & 0.918 & 1.089 \\
\hline
\end{tabular}

The type of IHE predicted satisfaction with the teaching-learning process and, to a lesser extent and negatively, age.

The results of the linear regression analysis in which the dependent variable introduced was the one related to the study techniques is presented in Table 7.

Table 7. Regression analysis regarding study techniques.

\begin{tabular}{|c|c|c|c|c|c|c|c|}
\hline \multirow[t]{2}{*}{ Variables } & \multicolumn{2}{|c|}{$\begin{array}{l}\text { Non-Standardized } \\
\text { Coefficients }\end{array}$} & \multirow{2}{*}{$\begin{array}{c}\text { Standardized } \\
\text { Coefficients }\end{array}$} & \multirow[t]{2}{*}{$t$} & \multirow{2}{*}{$p$} & \multicolumn{2}{|c|}{$\begin{array}{l}\text { Colinearity } \\
\text { Tests }\end{array}$} \\
\hline & B & SE & & & & TI & VIF \\
\hline Gender & 0.016 & 0.041 & 0.017 & 0.396 & 0.692 & 0.983 & 1.018 \\
\hline Type de IHE & 0.076 & 0.025 & 0.131 & $3.013^{* *}$ & 0.003 & 0.948 & 1.055 \\
\hline Academic year & -0.007 & 0.010 & -0.032 & -0.735 & 0.463 & 0.961 & 1.040 \\
\hline Age & -0.003 & 0.001 & -0.095 & $-2.147^{*}$ & 0.032 & 0.918 & 1.089 \\
\hline
\end{tabular}

The model was significant $(F=3260, p=0.012)$, and the data were not correlated $(d=1959)$, in addition to not finding multicollinearity.

The type of IHE was the variable that best predicted the study techniques used. Age was also a negative predictor. 


\section{Discussion}

The first objective of this research was to evaluate the learning of Brazilian university students considering study techniques, satisfaction with the teaching-learning process and with the educational infrastructure, based on three variables: gender, institution of higher education and the academic year. As can be seen in the results, no statistically significant differences were obtained regarding gender. Although the Pedagogy Degree is studied mostly by women, this is an important result since women in Latin America and the Caribbean have historically faced a situation of inequality with respect to access to education and since the positive relation between the level of education and salary has been highlighted [108]. This result agrees with those of previous authors, who found no differences in learning self-regulation strategies [56-59], in satisfaction with the teachinglearning process [86] or even in happiness [109] depending on gender. These results differ, however, from other studies that showed how women used more self-regulation strategies than men $[50,53,55]$, by using more metacognitive testing, elaboration, organization and processing tools [52]; as well as that women are those who show a lower level of satisfaction with the teaching-learning process [74]. The fact that no gender differences were found in the present study may be due to the university education becoming increasingly egalitarian, a transformation that has taken place in parallel with the historical-social changes in terms of the perception of their rights and their autonomy in the various areas of their lives [110]. In fact, in 2015, for the first time in a country like Spain, the percentage of female graduates was $56 \%$, very close to the OECD average (57\%) and the EU22 (59\%) [111].

However, other authors point out that the influence of this variable is mediated by other factors such as age [61], which will be discussed later, or the type of degree they are studying [60]. It should be noted that women continue to be underrepresented in science, technology, engineering and mathematics (STEM) careers, especially in GEMP careers (geosciences, engineering, economics, math/computer science, and physical science), which are the careers that continue to generate the highest income [112,113].

Regarding the institution, statistically significant differences were found in the type of IHE, both in study techniques, and in satisfaction with the infrastructure and teachinglearning processes. In all cases, it was private institutions, which scored the highest. With respect to satisfaction with the infrastructure, there were statistically significant differences in the type of IHE in all the variables (support infrastructure-external services, support infrastructure-internal services, library resources, technological resources), except in classroom facilities. This last result is very relevant since some authors have highlighted the importance of classroom facilities - the most basic facilities-in the general satisfaction with the infrastructure of the students [10]. However, in other resources, for example, the library, which is more dependent on financial resources, there were statistically significant differences depending on the type of IHE and this is also a very essential variable for student satisfaction [78]. This situation has already been highlighted in other studies, where private education students report receiving more guidance and better treatment from their teachers [114]. It should be noted that in Brazil, there is still a marked difference between private and public universities. As some authors state [115], legislators have yet to explore and implement more tools to monitor and improve the quality of the Brazilian public education system, bearing in mind the data regarding student satisfaction or their employability. This would improve, in turn, the general image of these institutions [91]. The system of HTVE (Higher Technical and Vocational Education) colleges, which are mainly public, still faces important challenges in Brazil, such as the standardization of studies, poor coordination with the labour market or the high dropout rate of students [115]. The fact that the studies are not yet sufficiently standardized may be one of the variables that have been able to influence the lower satisfaction of students from public institutions with the teaching-learning process and that has also been able to influence satisfaction with their own study techniques. However, this situation and the results obtained in the present study could be reversed in the future, since in a few years, the number of HTVE colleges is growing exponentially and they have been installed in more than $10 \%$ of 
Brazilian cities [116]. This expansion implies public policies that promote economic and social development and offer greater opportunities, especially for the most vulnerable, to study, for employability and to increase satisfaction with these institutions [116-118].

Another of the most influential variables in study techniques and student satisfaction with the infrastructure is the academic year. Specifically, it is first-year students who most positively value the aspects related to the infrastructure of their university (in all subscales: external services, internal services, library resources, classroom facilities and technological resources) and their study techniques (especially their learning strategies). Regarding infrastructure, this result contrasts with other studies where it is graduates, who have completed the entire degree, who best value infrastructure compared to students who continue studying at university [119]. On the other hand, some previous research indicates that it is the students of higher levels who develop more and more effective learning strategies than those used by students of lower grades [51,54]. Other research, however, supports a detriment of effort in higher levels compared to lower ones [52], which agrees with the results of the present study, or even establishes that there is no clear evidence that students at higher levels develop strategies for deeper or more elaborate learning [62].

The second objective of this study was to analyze the influence of age, gender, academic year, and institution on the general satisfaction of students with respect to the educational infrastructure, the teaching-learning process and the study techniques used. Again gender did not present statistically significant values; while the type of IHE and the academic year showed predictive values in satisfaction with the infrastructure; the type of IHE and the age they did with respect to the teaching-learning process; and the type of IHE and the age in terms of study techniques. As previously discussed, an inverse relationship was observed in the academic year, that is, the higher the grade, the less satisfaction with the infrastructure. However, the academic year was not found to have a predictive value in Study Techniques. This same inverse relationship occurred in the age variable (the older the lower score) in satisfaction with the teaching-learning processes and study techniques, so it may be deduced that, although the academic year influences study techniques, this influence may be mediated by the age [61] or the maturity of the student when using them.

This research provides valuable information on the processes of self-regulation and external regulation of learning and satisfaction with these aspects in Brazilian students, nevertheless, not without limitations and possible improvements. Future research should clarify some of the issues raised here. Some of these are the reasons why students in higher academic years and ages use fewer study techniques or are more dissatisfied with the infrastructure or also with the teaching-learning processes. The fact that at higher levels, less study techniques are used instead of more, can be seen as a contradiction, so it would be necessary to include other variables, possibly mediators, that abound in this direction. One might wonder if students abandon some of these techniques throughout their careers because they are not entirely useful or do not have a direct impact on their performance. Following this approach, it could be investigated, for example, whether or not there is direct teaching of these techniques by teachers or if other traditional study techniques are added that might improve student's concentration, performance and help to cope with academic life, such as the practice of mindfulness [120]. Another aspect to explore might be the influence of the COVID-19 pandemic and the new university setting, with a greater presence of virtual formats, on student satisfaction, especially with teaching-learning processes.

\section{Conclusions}

The most relevant corollaries of the present study refer, firstly, to the importance of evaluating the factors that influence self-regulation and external regulation of learning and the satisfaction of university students with these aspects.

Firstly, it has been shown that the type of IHE affects both satisfaction with the infrastructure and with the teaching-learning processes, as well as study techniques; and it is one of the greatest predictors of student satisfaction with these variables. 
Secondly, the academic year is another of the predictors of satisfaction with the infrastructures, with those in the first year being the most satisfied with respect to those in higher academic years. This same first-year student is the one that uses the most study techniques, specifically, learning strategies. However, this last aspect may be mediated by age, as this is one of the variables with the highest predictive value in study techniques, as well as in Satisfaction with the teaching-learning processes. The influence of age was also inverse, that is, the older the age, the lower the use of study techniques and the lower satisfaction with the teaching-learning processes.

Finally, no statistically significant differences were found in the scores of the scales based on gender, nor was it a variable with predictive value in any of them. This result shows that, in recent years, "The University has therefore managed to become an agent of transformation that promotes social development from the perspective of justice, solidarity and equal opportunities" (p. 11, [121]). Although these advances do not imply that there is still no path to traverse in pursuit of an education increasingly free of gender stereotypes.

Despite the importance of the results obtained in this study, especially in the comparison of public and private universities in Brazil, being a sample limited to a specific career, we cannot generalize for the general context of Brazil.

Author Contributions: Study conception and design, material preparation and analysis, L.H.T. and M.R.S.-S.d.Q.; data collection M.R.S.-S.d.Q.; writing-original draft preparation, L.H.T., L.C.S.-S. and T.R.-S.; writing-review, editing and supervision of the whole study, L.H.T., L.C.S.-S. and T.R.-S. All authors have read and agreed to the published version of the manuscript.

Funding: This research was co-financed by the Research Group Development, Education, Diversity, and Culture: Interdisciplinary Analysis (HUM-742). Also, it was supported by the Federal University of Maranhão and the Fundação de Amparo à Pesquisa e ao Desenvolvimento Científico e Tecnológico do Maranhão (Foundation for Research Support and Scientific and Technological Development of Maranhão).

Institutional Review Board Statement: The study was conducted according to the guidelines of the Declaration of Helsinki and approved by the Ethics Brazilian Committee (3.042.080) on 7 May 2018.

Informed Consent Statement: Informed consent was obtained from all subjects involved in the study.

Data Availability Statement: The data presented in this study are available on request from the corresponding author. The data are not publicly available due to privacy and ethical reasons.

Conflicts of Interest: The authors declare no conflict of interest.

\section{References}

1. Coertjens, L.; Donche, V.; De Maeyer, S.; Vanthournout, G.; Van Petegem, P. Modeling change in learning strategies throughout Higher Education: A multi-indicador latent growth perspective. PLoS ONE 2013, 8, e67854. [CrossRef]

2. Henríquez, P. Tendencias de la Educación Superior en América Latina y el Caribe 2018; UNESCO-IELSAC y UNC: Córdoba, Argentina, 2018.

3. Baeten, M.; Kyndt, E.; Struyven, K.; Dochy, F. Using student-centred learning environments to stimulate deep approaches to learning: Factors encouraging or discouraging their effectiveness. Educ. Res. Rev. 2010, 5, 243-260. [CrossRef]

4. Carbonero, M.A.; Martín-Antón, L.J.; Flores, V.; Freitas, A. Estudio comparado de los estilos de enseñanza del profesorado universitario de ciencias sociales de España y Brasil. Rev. Complut. Educ. 2017, 28, 631-647. [CrossRef]

5. Zineldin, M.; Akdag, H.C.; Vasicheva, V. Assessing quality in higher education: New criteria for evaluating students' satisfaction. Qual. High. Educ. 2011, 17, 231-243. [CrossRef]

6. Butt, B.Z.; Rehman, K. A study examining the students satisfaction in higher education. Procedia Soc. Behav. Sci. 2010, 2, 5446-5450. [CrossRef]

7. de la Fuente, J.; Sander, P.; Kauffman, D.F.; Yilmaz, M. Differential Effects of Self- vs. External-Regulation on Learning Approaches, Academic Achievement, and Satisfaction in Undergraduate Students. Front. Psychol. 2020, 11, 543884. [CrossRef]

8. Herrera, L. Evaluación de la docencia universitaria: Estudio predictivo de la satisfacción del alumnado con el aprendizaje en la educación superior. In Evaluación de los Aprendizajes en el Espacio Europeo de Educación Superior; Gómez, M., Grau, S., Eds.; Editorial Marfil: Alicante, Spain, 2010; pp. 587-604.

9. Herrera, L.; Jiménez, G.; Castro, A. Aprendizaje del alumnado universitario de primer y último curso de las titulaciones de Psicología y Magisterio. Rev. Electron. Investig. Psicoeduc. Psigopedag. 2011, 9, 659-691. [CrossRef] 
10. Martínez-Cervantes, T.J.; Soto-Mendivil, E.A.; Silva-Salazar, P.A.; Velasco-Arellanes, F.J. Efectos de la infraestructura básica en los resultados de la prueba ENLACE de la educación media superior tecnológica mexicana. REICE 2016, 11, 93-107.

11. Ribeiro, M.I.; Fernandes, A.; Correia, T. Satisfação com a vida académica em estudantes do ensino superior público português. Egitania Sci. 2013, 12, 63-79.

12. Arambewela, R.; Hall, J. An empirical model of international student satisfaction. Asia Pac. J. Mark. Logist. 2009, 21, 555-569. [CrossRef]

13. Hong, B.; Shull, P.; Haefner, L. Impact of perceptions of faculty on student outcomes of self-efficacy, locus of control, persistence, and commitment. J. Coll. Stud. Ret. 2011, 13, 289-309. [CrossRef]

14. Lenton, P. Determining student satisfaction: An economic analysis of the National Student Survey. Econ. Educ. Rev. 2015, 47, 118-127. [CrossRef]

15. Mena, L.; Fernández, M.; Riviére, J. Desenganchados de la educación: Procesos, experiencias, motivaciones y estrategias del abandono y del fracaso escolar. Rev. Binacional Bras. Argent. 2016, 5, 27-52.

16. Tuero, E.; Cervero, A.; Esteban, M.; Bernardo, A. ¿Por qué abandonan los alumnos universitarios? Variables de influencia en el planteamiento y consolidación del abandono. Educación XX1 2018, 21, 131-154. [CrossRef]

17. Hagström, E.; Lindberg, O. Three theses on teaching and learning in higher education. Teach. High. Educ. 2013, 18, 119-128. [CrossRef]

18. An, D.; Carr, M. Learning styles theory fails to explain learning and achievement: Recommendations for alternative approaches. Pers. Indiv. Differ. 2017, 116, 410-416. [CrossRef]

19. Erdogan, T.; Ozdemir, E. An investigation of learning approaches and language learning strategies: Are they related? Eur. J. Educ. Stud. 2018, 4, 91-106.

20. Hernández, H.C.; Rodríguez, P.N.; Vargas, G.A. Los hábitos de estudio y motivación para el aprendizaje de los alumnos en tres carreras de ingeniería. Rev. Educ. Sup. 2012, 3, 67-87.

21. Khan, M.; Rashid, S. Teaching Styles as Moderator between Metacognitive Awareness and Study Habits among University Students. J. Behav. Sci. 2018, 28, 67-84.

22. Pintrich, P.R.; Smith, D.; García, T.; McKeachie, W. A Manual for the Use of the Motivated Strategies for Learning Questionnaire (MSLQ); University of Michigan: Ann Arbor, MI, USA, 1991.

23. Donche, V.; De Maeyer, S.; Coertjens, L.; Van Daal, T.; Van Petegem, P. Differential use of learning strategies in first-year higher education: The impact of personality, academic motivation, and teaching strategies. Br. J. Educ. Psychol. 2013, 83, 238-251. [CrossRef] [PubMed]

24. Gozalo, M.; León-del-Barco, B.; Mendo-Lázaro, S. Good Practices and Learning Strategies of Undergraduate University Students. Int. J. Environ. Res. Public Health 2020, 17, 1849. [CrossRef]

25. de la Fuente, J.; Paoloni, P.V.; Vera-Martínez, M.; Garzón-Umerenkova, A. Effect of Levels of Self-Regulation and Situational Stress on Achievement Emotions in Undergraduate Students: Class, Study and Testing. Int. J. Environ. Res. Public Health 2020, 17, 4293. [CrossRef]

26. IHEkkilä, A.; Lonka, K. Studying in higher education: Students' approaches to learning, self-regulation, and cognitive strategies. Stud. High. Educ. 2006, 31, 99-117.

27. IHEkkilä, A.; Niemivirta, M.; Nieminen, J.; Lonka, K. Interrelations among university students' approaches to learning, regulation of learning, and cognitive and attributional strategies: A person oriented approach. High. Educ. 2011, 61, 513-529.

28. Vermunt, J.D.; Donche, V.A. Learning Patterns Perspective on Student Learning in Higher Education: State of the Art and Moving Forward. Educ. Psychol. Rev. 2017, 29, 269-299. [CrossRef]

29. Richardson, M.; Abraham, C.; Bond, R. Psychological correlates of university students' academic performance: A systematic review and meta-analysis. Psychol. Bull. 2012, 138, 353-387. [CrossRef] [PubMed]

30. Chen, J.; Guo, W. Emotional intelligence can make a difference: The impact of principals' emotional intelligence on teaching strategy mediated by instructional leadership. Educ. Manag. Adm. Leadersh. 2018, 48, 82-105. [CrossRef]

31. Mega, C.; Ronconi, L.; De Beni, R. What Makes a Good Student? How Emotions, Self-Regulated Learning, and Motivation Contribute to Academic Achievement. J. Educ. Psychol. 2014, 106, 121-131. [CrossRef]

32. Mirete, A.B.; Pérez, R.; Maquilón, J.J. Estudio comparativo de los enfoques de aprendizaje de los estudiantes de los Grados de Pedagogía y Educación Primaria. Educ. Siglo XXI 2018, 36, 173-194. [CrossRef]

33. Shahzadi, E.; Ahmad, Z. A study on academic performance of university students. In Proceedings of the 8th International Conference on Recent Advances in Statistics, Lahore, Pakistan, 8-9 February 2011; pp. 255-268.

34. Živčić-Bećirević, I.; Smojver-Ažić, S.; Martinac-Dorčić, T. Predictors of University Students' Academic Achievement: A Prospective Study. Drus. Istraz. 2017, 26, 457-476.

35. Cassidy, S. Self-regulated learning in higher education: Identifying key component processes. Stud. High. Educ. 2011, 36, 989-1000. [CrossRef]

36. Pintrich, P.R. The role of goal orientation in self-regulated learning. In Handbook of Self-Regulation: Theory, Research and Applications; Boekarts, M., Pintrich, P.R., Zeidner, M., Eds.; Academic: San Diego, CA, USA, 2000; pp. 451-525.

37. Pintrich, P.R. A Motivational Science Perspective on the Role of Student Motivation in Learning and Teaching Contexts. J. Educ. Psychol. 2003, 95, 667-686. [CrossRef] 
38. Zimmerman, B.J. Investigating Self-Regulation and Motivation: Historical Background, Methodological Developments, and Future Prospects. Am. Educ. Res. J. 2008, 45, 166-183. [CrossRef]

39. Pintrich, P.R.; García, T. Intraindividual differences in students' motivation and self-regulated learning. Ger. J. Educ. Psychol. 1993, 7, 99-107.

40. de la Fuente, J.; Justicia, F. Escala de Estrategias de Aprendizaje ACRA- Abreviada para Alumnos Universitarios. Rev. Electron. Investig. Psicoeduc. Psigopedag. 2003, 1, 140-158. [CrossRef]

41. de la Fuente, J.; Justicia, F. El modelo DIDEPRO de regulación de la enseñanza y del aprendizaje: Avances recientes. Rev. Electron. Investig. Psicoeduc. Psigopedag. 2007, 5, 535-564. [CrossRef]

42. Gudeva, L.; Dimova, V.; Daskalovska, N.; Trajkova, F. Designing descriptors of learning outcomes for Higher Education qualification. Procedia Soc. Behav. Sci. 2012, 46, 1306-1311. [CrossRef]

43. Muelas, A.; Navarro, E. Learning Strategies and Academic Achievement. Procedia Soc. Behav. Sci. 2015, 165, 217-221. [CrossRef]

44. Castro, A.; Herrera, L.; Enrique, C. Conclusiones, retos y desafíos para la Educación Superior en el contexto del EEES. In Retos y Desafíos Actuales de la Educación Superior Desde la Perspectiva del Profesorado Universitario; Herrera, L., Ed.; Síntesis: Madrid, Spain, 2015; pp. 205-218.

45. Gargallo, B.; Pérez-Pérez, C.; García-García, F.; Giménez, J.A.; Portillo, N. La competencia aprender a aprender en la universidad: Propuesta de modelo teórico. Educación XX1 2020, 23, 19-44. [CrossRef]

46. Prince, M. Does Active Learning Work? A Review of the Research. J. Eng. Educ. 2004, 93, 223-231. [CrossRef]

47. Kobayashi, K. What limits the encoding eVect of note-taking? A meta-analytic examination. Contemp. Educ. Psychol. 2005, 30, 242-262. [CrossRef]

48. Salgado-Horta, D.; Maz-Machado, A. Toma de apuntes y aprendizaje en estudiantes de Educación Superior. Rev. Complut. Educ. 2013, 24, 341-358. [CrossRef]

49. de la Fuente, J.; Pichardo, M.C.; Justicia, F.; Berbén, A. Learning approaches, self-regulation and achievement in three European universities. Psicothema 2008, 20, 705-711. [PubMed]

50. Downing, K.; Chan, S.; Downing, W.; Kwong, T.; Lam, T. Measuring gender differences in cognitive functioning. Multicul. Educ. Technol. J. 2008, 2, 4-18. [CrossRef]

51. Gargallo, B. Estrategias de aprendizaje, rendimiento y otras variables relevantes en estudiantes universitarios. Rev. Psicol. Gen. Apl. 2006, 59, 109-130.

52. Lynch, D.J. Confronting challenges: Motivational beliefs and learning strategies in difficult college courses. Coll. Stud. J. 2008, 42, 416-421.

53. Pintrich, P.R.; Zusho, A. Student motivation and self-regulated learning in the college classroom. In The Scholarship of Teaching and Learning in Higher Education: An Evidence-Based Perspective; Perry, R., Smart, J.C., Eds.; Springer: Dordrecht, The Netherlands, 2007; pp. 731-810.

54. Taasoobshirazi, G.; Carr, M. A structural equation model of expertise in college physics. J. Educ. Psychol. 2009, 101, 630-643. [CrossRef]

55. Virtanen, P.; Nevgi, A. Disciplinary and gender differences among higher education students in self-regulated learning strategies. Educ. Psychol. 2010, 30, 323-347. [CrossRef]

56. Hong, E.; Peng, Y.; Rowell, L.L. Homework self-regulation: Grade, gender, and achievement-level differences. Learn. Individ. Differ 2009, 19, 269-276. [CrossRef]

57. Nisbet, D.L.; Tindall, E.R.; Arroyo, A.A. Language learning strategies and English proficiency of Chinese university students. Foreign Lang. Ann. 2005, 38, 100-107. [CrossRef]

58. Psaltou-Joycey, A. Cross-cultural differences in the use of learning strategies by students of Greek as a second language. J. Multiling. Multicult. Dev. 2008, 29, 310-324. [CrossRef]

59. Yukselturk, E.; Bulut, S. Gender differences in self-regulated online learning environment. J. Educ. Technol. Soc. 2009, 12, 12-22.

60. Cano, F. Diferencias de género en estrategias y estilos de aprendizaje. Psicothema 2000, 12, 360-367.

61. Rubin, M.; Scevak, J.; Southgate, E.; Macqueen, S.; Williams, P.; Douglas, H. Older women, deeper learning, and greater satisfaction at university: Age and gender predict university students' learning approach and degree satisfaction. J. Divers. High. Educ. 2018, 11, 82-96. [CrossRef]

62. Asikainen, H.; Gijbels, D. Do students develop towards more Deep approaches to learning during studies? A systematic review on the development of students' deep and surface approaches to learning in higher education. Educ. Psychol. Rev. 2017, 29, 205-234. [CrossRef]

63. Bezuidenhout, G.; De Jager, J. Clients' service perceptions of private higher education institutions in South Africa: An importanceperformance analysis for strategic managers. Afr. J. Bus. Manag. 2014, 8, 55-67.

64. Green, H.; Hood, M.; Neumann, D. Predictors of student satisfaction with university psychology courses: A review. Psychol. Learn. Teach. 2015, 14, 131-146. [CrossRef]

65. Gruber, T.; Fuß, S.; Voss, R.; Glaser-Zikuda, M. Examining student satisfaction with higher education services. Int. J. Public Sect. Manag. 2010, 23, 105-123. [CrossRef]

66. Gibson, A. Measuring business student satisfaction: A review and summary of the major predictors. J. High. Educ. Policy Manag. 2010, 32, 251-259. [CrossRef] 
67. Elliott, K.M.; Shin, D. Student Satisfaction: An alternative approach to assessing this important concept. J. High. Educ. Policy Manag. 2002, 24, 197-209. [CrossRef]

68. Duque, L.C.; Weeks, J.R. Towards a model and methodology for assessing student learning outcomes and satisfaction. Qual. Assur. Educ. 2010, 18, 84-105. [CrossRef]

69. Wilkins, S.; Balakrishnan, M.S. Assessing student satisfaction in transnational higher education. Int. J. Educ. Manag. 2013, 27, 143-156. [CrossRef]

70. Sojkin, B.; Bartkowiak, B.; Skuza, A. Determinants of higher education choices and student satisfaction: The case of Poland. High. Educ. 2012, 63, 565-581. [CrossRef]

71. Helgesen, O.; Nesset, E. What accounts for students' loyalty? Some field study evidence. Int. J. Educ. Manag. 2007, 21, 126-143. [CrossRef]

72. Law, D. Quality assurance in post-secondary education: The student experience. Qual. Assur. Educ. 2010, 18, 250-270.

73. Jereb, E.; Jerebic, J.; Urh, M. Revising the Importance of Factors Pertaining to Student Satisfaction in Higher Education. Organizacija 2018, 51, 271-285. [CrossRef]

74. Poon, J. Postgraduate student satisfaction in the UK. Prop. Manag. 2019, 37, 115-135. [CrossRef]

75. Shah, M.; Nair, C.; Bennett, L. Factors influencing student choice to study at private higher education institutions. Qual. Assur. Educ. 2013, 21, 402-416. [CrossRef]

76. Deuren, R.; Lhaden, K. Student satisfaction in higher education: A comparative study of a private and a public college. Bhuthan J. Res. Dev. 2017, 6, 40-52.

77. Marzo, M.; Pedraja, M.; Rivera, P. A new management element for universities: Satisfaction with the offered courses. Int. J. Educ. Manag. 2005, 19, 505-526. [CrossRef]

78. Tsinidou, M.; Gerogiannis, V.; Fitsilis, P. Evaluation of the factors that determine quality in higher education: An empirical study. Qual. Assur. Educ. 2010, 18, 227-244. [CrossRef]

79. Arif, S.; Ilyas, M.; Hameed, A. Student satisfaction and impact of leadership in private universities. TQM J. 2013, 25, 399-416. [CrossRef]

80. Mazumder, Q. Analysis of Quality in Public and Private Universities in Bangladesh and USA. Int. J. Eval. Res. Educ. 2014, 3, 99-108. [CrossRef]

81. Sayeda, B.; Rajendran, J.; Lokachari, P.S. An empirical study of total quality management in engineering educational institutions of India: Perspective of management. Benchmarking Int. J. 2010, 17, 728-767. [CrossRef]

82. Manzoor, H. Measuring Student Satisfaction in Public and Private Universities in Pakistan. Glob. J. Manag. Bus. Res. Interdiscip. 2013, 13, 209-219.

83. Peralta, E.; Súrdez, E.G.; García, J.F. Validación de modelo de medición de satisfacción estudiantil universitaria con los servicios académicos recibidos. Rev. Investig. Operacional 2020, 41, 472-481.

84. Parpala, A.; Lindblom-Ylänne, S.; Komulainen, E.; Litmanen, T.; Hirsto, L. Students' approaches to learning and their experiences of the teachinglearning environment in different disciplines. Br. J. Educ. Psychol. 2010, 80, 269-282. [CrossRef]

85. Gurpinar, E.; Kulac, E.; Tetik, C.; Akdogan, I.; Mamakli, S. Do learning approaches of medical students affect their satisfaction with problem-based learning? Adv. Physiol. Educ. 2013, 37, 85-88. [CrossRef]

86. O'Driscoll, F. What matters most. An exploratory multivariate study of satisfaction among first year hotel/hospitality management students. Qual. Assur. Educ. 2012, 20, 237-258. [CrossRef]

87. Álvarez, J.; Chaparro, E.M.; Reyes, D.E. Study of Student Satisfaction with the Educational Services to Universities of the Toluca Valley. REICE 2014, 13, 5-26.

88. Karami, M.; Olfati, O. Measuring service quality and satisfaction of students: A case study of students' perception of service quality in high-ranking business schools in Iran. Afr. J. Bus. Manag. 2012, 6, 658-669.

89. Abbasi, M.; Malik, A.; Chaudhry, I.; Imdadullah, M. A Study on Student Satisfaction in Pakistani Universities: The Case of Bahauddin Zakariya University, Pakistan. Asian Soc. Sci. 2011, 7, 209-219. [CrossRef]

90. Naidu, P.; Derani, N.A. Comparative Study on Quality of Education Received by Students of Private Universities versus Public Universities. Procedia Econ. Financ. 2016, 35, 659-666. [CrossRef]

91. Oliveira, J.H.; Sousa, G.H.; Miller, G.; Coser, R.; Lizarelli, F.L. Antecedents and consequents of student satisfaction in higher technical-vocational education: Evidence from Brazil. Int. J. Educ. Vocat. Guid. 2019, 20, 351-373.

92. Ardi, R.; Hidayatno, A.; Zagloel, T.Y.M. Investigating relationships among quality dimensions in higher education. Qual. Assur. Educ. 2012, 20, 408-428. [CrossRef]

93. Bullón, S.R. La Satisfacción Estudiantil con la Calidad Educativa de la Universidad. Ph.D. Thesis, Pontificia Universidad Católica del Perú, Lima, Perú, 2007.

94. Devlin, M.; Samarawickrema, G. The criteria of effective teaching in a changing higher education context. High. Educ. Res. Dev. 2010, 29, 111-124. [CrossRef]

95. Gargallo, B.; Suárez, J.; Garfella, P.R.; Fernández, A. El cuestionario CEMEDEPU. Un instrumento para la evaluación de la metodología docente y evaluativa de los profesores universitarios. Estud. Sobre Educ. 2011, 21, 9-40.

96. Barbero, M.I. Psicometría; UNED: Madrid, Spain, 2006. 
97. Herrera, L.; Gallardo, M.A. Diseño de cuestionarios de evaluación para el alumnado participante en Proyectos de Innovación Tutorial. In I Congreso Internacional de Psicopedagogía: Ámbitos de Intervención del Psicopedagogo; Gallardo, M.A., Herrera, L., Rodríguez, S., Rojas, G., Seijo, D., Villena, J.L., Fernández, A.M., Fuentes, J.A., Molina, E., Carrillo, P., Eds.; Proyecto de Innovación Docente "Plan de Mejora y Evaluación del Prácticum de Psicopedagogía en Melilla": Granada, Spain, 2006; pp. 1-18.

98. International Test Commission. ITC Guidelines for Translating and Adapting Tests. 2005. Available online: https://www. intestcom.org/files/guideline_test_adaptation.pdf (accessed on 18 March 2018).

99. Muñiz, J.; Elosua, P.; Hambleton, R. International test commission guidelines for test translation and adaptation: Second edition. Psicothema 2013, 25, 151-157.

100. Herrera, L.; Lorenzo, O. Estrategias de aprendizaje en estudiantes universitarios. Un aporte a la construcción del Espacio Europeo de Educación Superior. Educ. Educad. 2009, 12, 75-98.

101. Osborne, J.W. Best Practices in Data Cleaning: A Complete Guide to Everything You Need to Do before and after Collecting Your Data; SAGE Publications: Thousand Oaks, CA, USA, 2012.

102. Norman, G. Likert scales, levels of measurement and the "laws" of statistics. Adv. Health Sci. Educ. 2010, 15, 625-632. [CrossRef]

103. Warner, R.M. Applied Statistics: From Bivariate through Multivariate Techniques; SAGE Publications: Thousand Oaks, CA, USA, 2008.

104. Lakens, D. Calculating and reporting effect sizes to facilitate cumulative science: A practical primer for $t$-tests and ANOVAs. Front. Psychol. 2013, 4, 863. [CrossRef]

105. Durbin, J.; Watson, G.S. Testing for serial correlation in least squares regression, II. Biometrika 1951, 38, 159-178. [CrossRef]

106. Belsley, D.A. Conditioning Diagnostics: Collinearity and Weak Data in Regression; John Wiley \& Sons: New York, NY, USA, 1991.

107. Berry, W.D.; Feldman, S. Multiple Regression in Practice; SAGE Publications: Thousand Oaks, CA, USA, 1985.

108. Trucco, D. Educación y desigualdad en América Latina; Naciones Unidas: Santiago de Chile, Chile, 2014.

109. Caballero-García, P.A.; Sánchez-Ruíz, S. La felicidad en estudiantes universitarios. ¿Existen diferencias según género, edad o elección de estudios? Rev. Electron. Interuniv. Form. Profr. 2018, 21,1-18. [CrossRef]

110. Graña, F. El asalto de las mujeres a las carreras universitarias "masculinas": Cambio y continuidad en la discriminación de género. PRAXIS Educ. 2012, 12, 77-86.

111. Ministerio de Educación, Cultura y Deporte (MECD). Panorama de la Educación. Indicadores de la OCDE 2017. Informe Español; Secretaría General técnica. Subdirección General de Documentación y Publicaciones: Madrid, Spain, 2017.

112. Buser, T.; Niederle, M.; Oosterbeek, H. Gender, competitiveness, and career choices. Q. J. Econ. 2014, 129, 1409-1447. [CrossRef]

113. Kahn, S.; Ginther, D.K. Women and STEM. In The Oxford Handbook on the Economics of Women; Averett, S.L., Argys, L.M., Hoffman, S.D., Eds.; Oxford University Press: New York, NY, USA, 2017; pp. 767-798. [CrossRef]

114. Ortega, F.Z.; Garofano, V.V.; Ruz, R.P.; González, M.C. Niveles de satisfacción hacia el grado de maestro en alumnos de último curso. Profr. Rev. Curríc. Form. Profr. 2017, 21, 349-367.

115. Almeida, R.; Amaral, N.; de Felicio, F. Assessing Advances and Challenges in Technical Education in Brazil; World Bank: Washington, DC, USA, 2015. [CrossRef]

116. de Faveri, D.B.; Petterini, F.C.; Barbosa, M.P. Uma avaliação do impacto da política de expansão dos Institutos Federais nas economias dos municípios brasileiros. Planej. Políticas Públicas 2018, 50, 125-147.

117. Pacheco, I.J.D.; Mesquita, J.M.C.; Dias, A.T. Qualidade Percebida e Satisfação dos Alunos da Rede Federal de Educação Profissional e Tecnológica. Rev. Gestão Tecnol. 2015, 15, 5-28.

118. SETEC/MEC. Políticas Públicas Para a Educação Profissional e Tecnológica; SETEC/MEC: Brasília, Brazil, 2004.

119. Herrera, L.; Tomé, M.; Perandones, T.M.; Sánchez-Sánchez, L.C. Estudio de seguimiento del alumnado universitario de grado y satisfacción de los empleadores. Análisis cuantitativo. In Inserción Profesional y Seguimiento de Egresados. Una Perspectiva Multicultural; Lorenzo Quiles, O., Ed.; Síntesis: Madrid, Spain, 2021; pp. 137-194.

120. Sánchez-Sánchez, L.C.; Perandones, T.M. Mindfulness y técnicas de estudio en un caso de bajo rendimiento académico. Int. J. Dev. Educ. Psychol. INFAD Rev. Psicol. 2019, 3, 13-20. [CrossRef]

121. Martín Rodrigo, M.J. Influencia de los Estereotipos de Género en la Elección de Estudios Universitarios; Universidad Pontificia de Comillas: Madrid, Spain, 2018. 